Muhammad Al Kholif \& Rhenny Ratnawati : Pengaruh Beban Hidrolik Media Dalam Menurunkan Senyawa Ammonia Pada Limbah Cair Rumah Potong Ayam (RPA)

\title{
PENGARUH BEBAN HIDROLIK MEDIA DALAM MENURUNKAN SENYAWA AMMONIA PADA LIMBAH CAIR RUMAH POTONG AYAM (RPA)
}

\author{
Oleh \\ Muhammad Al Kholif ${ }^{(1)}$ dan Rhenny Ratnawati ${ }^{(1)}$ \\ (1) Program Studi Teknik Lingkungan, Fakultas Teknik Sipil dan Perencanaan (FTSP) \\ Universitas PGRI Adi Buana Surabaya. \\ Email : milanisti.alkholif@gmail.com
}

\begin{abstract}
Abstrak :
Limbah rumah potong ayam (RPA) umumnya mengandung zat pencemar seperti Biological Oxygen Deman (BOD), Chemical Oxygen Deman (COD) dan Amonia yang tinggi. Umumnya senyawa pencemar tersebut terbentuk dalam pencernaan lipid. Kandungan ammonia pada limbah rumah potong ayam umumnya melebihi baku mutu yang sudah ditetapkan. Biofilter anaerob merupakan salah satu metode pengolahan limbah cair yang dapat diterapkan untuk mengolah air limbah RPA. Tujuan yang ingin dicapai adalah mengkaji kemampuan beban hidrolik media dalam menurunkan senyawa amonia pada air limbah RPA. Beban hidrolik media yang digunakan terdiri

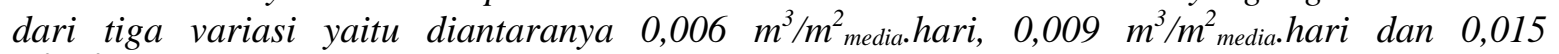
$\mathrm{m}^{3} / \mathrm{m}^{3}$ media.hari. Media yang digunakan dalam penelitian ini yaitu media karbon aktif untuk menurunkan beban pencemar ammonia pada air limbah RPA dengan sistem biofilter anaerob tercelup aliran upflow. Reaktor yang digunakan dalam percobaan ini adalah terdiri dari 3 reaktor dengan ukuran berbeda-beda. Efisiensi penyisihan kandungan amonia disimpulkan bahwa penerapan beban hidrolik media $0,006 \mathrm{~m}^{3} / \mathrm{m}^{2}$ media.hari mampu menyisihkan senyawa ammonia lebih dari $95 \%$.
\end{abstract}

Kata Kunci : Senyawa Ammonia, Limbah Cair RPA, Beban Hidrolik Media, Media Karbon Aktif.

\begin{abstract}
Wastewater chicken slaughterhouse generally contains contaminants such as Biological Oxygen Deman (BOD), Chemical Oxygen Deman (COD) and ammonia which high. Generally, these pollutants are compounds formed hearts lipid digestion. The content of ammonia on chicken slaughterhouse wastes generally exceeds quality which has been set. The anaerobic biofilter is prayer processing method the liquid waste can be applied to the review process the waste chicken slaughterhouse. Interest want achieved is assessing the ability expenses hydraulic media hearts Lowering ammonia compounds waste in chicken slaughterhouse. Media used hydraulic load consists from three variations that is among $0006 \mathrm{~m}^{3} / \mathrm{m}^{2}$ media.day, $0009 \mathrm{~m}^{3} / \mathrm{m}^{2}$ media.day and 0015 $\mathrm{m}^{3} / \mathrm{m}^{2}$ media.day. media used hearts research singer namely carbon active media cost on to review lowering pollutant ammonia on with chicken slaughterhouse waste submerged upflow anaerobic biofilter system flow. Experimental reactor used hearts singer is comprised of the 3 reactors with different sizes vary. The content of ammonia removal efficiency was concluded that the application of media hydraulic load $0,006 \mathrm{~m}^{3} / \mathrm{m}^{2}$ media.day capable designated ammonia more than $95 \%$.
\end{abstract}

Keyworld : Ammonia, Wastewater chicken slaughterhouse, Media hydraulic load, Active Carbon Media. 


\section{PENDAHULUAN}

Limbah Rumah Potong Ayam (RPA) berpotensi menghasilkan substrat yang baik untuk produksi biogas karena konsentrasi yang tinggi pada protein dan lipid. Namun, dalam penelitian skala laboratorium OLRs relatif rendah yaitu hanya $(0,8-1,7 \mathrm{~kg}$ $\mathrm{VS} / \mathrm{m}^{3}$.hari) dengan HRTs $25-100$ hari dalam pencernaan anaerobik limbah rumah potong hewan telah terlihat kelayakannya (Bayr et al., 2012; Cuetos et al., 2008; Salminen and Rintala, 2002) karena tingginya isi materi protein dan lemak sehingga menyebabkan ketidakstabilan antara produk dari proses pencernaan, yaitu amonia nitrogen $\left(\mathrm{NH}_{4}{ }^{-} \mathrm{N}\right)$, asam volatil lemak (VFAs) dan rantai panjang asam lemak (LCFAs). Amonia terbentuk dalam pencernaan anaerobik protein dan rantai panjang asam lemak yang terbentuk dalam pencernaan lipid. Amonia nitrogen terdiri dalam dua bentuk, yaitu ion ammonia $\left(\mathrm{NH}_{4}^{+}\right)$dan amonia nitrogen bebas $\left(\mathrm{NH}_{4}\right)$, yang dianggap sebagai penghambat dalam proses pencernaan anaerobik (Koster dan Koomen, 1988). Konsentrasi dari setiap proses tergantung pada suhu dan $\mathrm{pH}$, semakin tinggi suhu, maka semakin tinggi konsentrasi amonia bebas. Dalam penelitian terbaru (Karlsson dan Ejlertsson, 2012) menunjukkan bahwa penambahan $\mathrm{HCl}$ untuk menurunkan pH 8 ke 7,6 dan 7,8 akan meningkatkan gas metana pada reaktor skala laboratorium CSTR dalam mengolah limbah pemotongan hewan.

Jumlah dan karakteristik air limbah di industri RPA ini sangat bervariasi tergantung pada proses industri dan air yang digunakan tiap melakukan aktivitas pemotongan ayam (Del Nery et al., 2001a). Menurut Del and Damianovic dalam Tarntip dan Thungkao (2011), pemotongan ayam akan menghasilkan limbah cair terutama di proses pemotongan dan pencucian karkas. Kandungan limbah cair RPA diantaranya adalah limbah kimia-fisik dan mikrobiologi. Mikroba yang terkandung dalam limbah cair RPA diantaranya adalah Bacillus subtilis, Bacillus thuringiensis, dan Lysinibacillus fusiformis (Tarntip dan Thungkao, 2011).

Amonia dapat diolah dan dihilangkan oleh reaksi biologis. Reaksi berurutan antara
Nitrifikasi dan denitrifikasi merupakan proses biologis untuk mengolah dan menghilangkan amonium, dalam bentuk gas $\mathrm{N}_{2}$ (Munch et al, 1996;. Obaja et al, 2003). Proses Anammox adalah proses biologis lain untuk menghilangkan amonia, bersamaan mengkonversi $\mathrm{NH}_{4}{ }^{+} / \mathrm{NO}_{2}{ }^{-}$menjadi gas $\mathrm{N}_{2}$ melalui reaksi biologis bakteri Anammox (Jetten et al., 2001). Proses-proses teknologi secara biologis sudah terbukti dan didistribusikan dengan baik di instalasi pengolahan air limbah. Baru-baru ini, Kim et al. (2008) penghilangan amonia yang diusulkan oleh reaksi bio elektrokimia menggunakan sistem sel bahan bakar mikroba (MFC). Berbeda dengan proses penyisihan amonia, dengan sistem MFC menunjukan energi listrik positif yang dihasilkan selama penghapusan amonia yang terkandung dalam sampah organik. Sejak Kuntke et al. (2012) melaporkan penggunaan sistem MFC dalam pemulihan amonia, penghapusan bioelectrochemical amonia pada sistem MFC merupakan hal yang jauh lebih penting untuk para peneliti yang menginginkan teknologi energi lingkungan hemat energi.

Dalam kasus ini air limbah dari indutri RPA akan diolah menerapkan sistem biofilter anaerobic dengan media karbon aktif. Kondisi awal air limbah untuk parameter utama seperti Biological Oxygend Demand (BOD), Chemical Oxygend Demand (COD), Total Suspended Solid (TSS) dan ammonia masih di atas ambang batas limbah cair rumah potong hewan (RPH) yang ditetapkan oleh Peraturan Gubernur Jawa Timur No. 72 Tahun 2013. Data awal air limbah RPA sebelum dilakukan pengolahan untuk kadar BOD sebesar $1.648 \mathrm{mg} / \mathrm{L}$, kadar COD sebesar $2.573 \mathrm{mg} / \mathrm{L}$, TSS sebesar $1.130 \mathrm{mg} / \mathrm{L}$ dan kadar ammonia yaitu sebesar 141,28 $\mathrm{mg} / \mathrm{L}$, sedangkan yang disyaratkan oleh Peraturan Gubernur Jawa Timur No. 72 Tahun 2013 adalah khususnya kadar ammonia adalah $25 \mathrm{mg} / \mathrm{L}$. Penelitian ini dilakukan dengan menerapkan variasi beban hidrolik media untuk menyisihkan senyawa ammonia pada air limbah RPA. Jika dikaji dari penelitian sebelumnya yang dilakukan (Al Kholif, $M$ dan Hermana J, 2013) 
penggunaan beban hidrolik media 0006 $\mathrm{m}^{3} / \mathrm{m}^{2}$ media.hari mampu mengurangi kandungan COD sebesar 96,32\%, sedangkan yang dilakukan (Sugito, et al 2016) dalam mengolah air limbah RPA dengan konsentrasi awal limbah sebesar $380 \mathrm{mg} / \mathrm{L}$ mampu menyisihkan kadar BOD sebesar 98,08\%. Dari kajian tersebut diyakini bahwa biofilter anaerob juga mampu menyisihkan kadar ammonia pada air limbah RPA.

\section{METODE \\ Sampel Penelitian}

Sampel yang digunakan dalam percobaan ini merupakan limbah cair RPA setelah proses pencabutan bulu selesai. Limbah cair RPA yang diambil sebagai sampel percobaan merupakan sampel asli sehingga terlihat mengandung adalah. Umumnya keberadaan darah menunjukan tingkat karakteristik air limbah. Semakin banyak kadar darahnya, maka semakin banyak senyawa pencemar yang disumbangkan ke lingkungan. Dalam penelitian ini dilakukan beberapa perlakuan yaitu sampel tanpa pengenceran dan sampel dengan perlakuan pengenceran 2 kali dan 4 kali. Tanpa pengenceran artrinya air limbah RPA merupakan air limbah asli sedangkan pengenceran 2 kali dan 4 kali dilakukan sesuai dengan jumlah volume limbah yang diambil.

\section{Peralatan dan Bahan Percobaan}

Dalam penelitian ini alat dan bahan yang digunakan adalah :

a. Alat

Reaktor biofilter anaerobik dari akrilik dengan ketebalan $5 \mathrm{~mm}$, tandon air dari plastik, pipa PVC dan sambungannya, pompa, penyangga, media karbon aktif, pipet dan jirigen. Reaktor biofilter anaerob kemudian diisi oleh media karbon aktif sebagai media pertumbuhan mikroorganisme yang diharapkan akan menyerap senyawa ammonia.

b. Bahan

Limbah cair RPA yang diambil langsung pada drum pencucian ayam setelah proses pencabutan bulu.
Gambar potongan memanjang model reaktor Biofilter anaerob tercelup dan peralatan pelengkap yang digunakan dalam penelitian ini adalah seperti Gambar 1 .

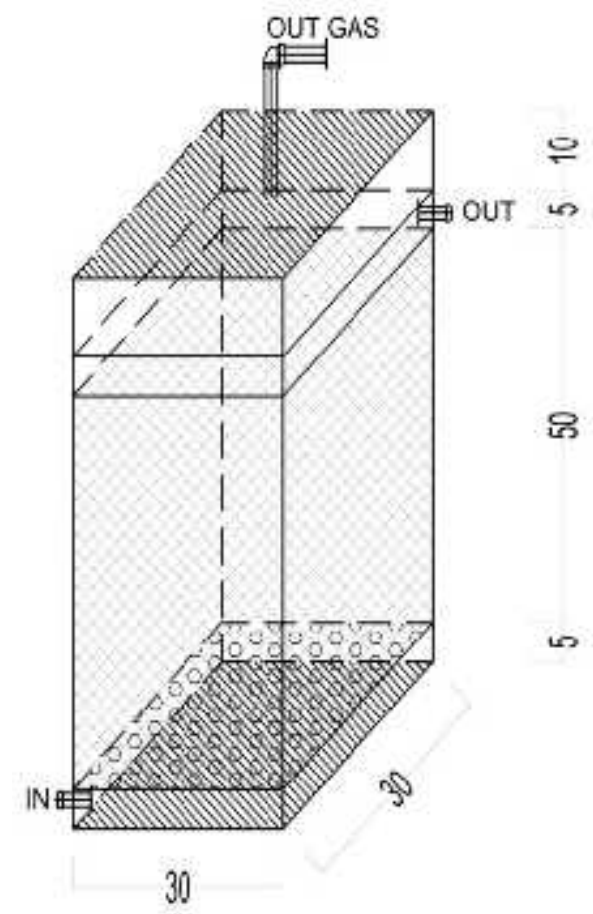

Gambar 1. Model Reaktor Penelitian

\section{Tahap Pengumpulan Data}

Pengumpulan data dilakukan dengam menggunakan metode observasi antara lain:

a. Analisis kualitas air limbah awal, meliputi parameter lengkap seperti BOD, COD dan amonia.

b. Prosedur pengoperasian reaktor biofilter adalah sebagai berikut:

1) Mengatur konsentrasi influen air limbah yang masuk ke dalam reaktor dengan menggunakan valve sesuai dengan debit yang diinginkan yaitu sebesar $0,05 \mathrm{~m}^{3} /$ hari. Media biofilter yang yang digunakan dalam penelitian ini adalah media karbon aktif.

2) Effluen dari biofilter diambil dan dianalisis sesuai dengan parameter yang diukur secara berkala. Pengukuran parameter ammonia dilakukan dengan analisis sebelum dan sesudah pengolahan.

c. Prosedur analisis amonia dilakukan setelah didapatkan hasil dari nilai kalibrasi 
antara reagen dan sampel. Dari hasil pengamatan di laboratorium didapatkan hasil dari kalibrasi antara reagen dan sampel limbah RPA dengan menggunakan spektrofotometri pada panjang gelombang $410 \mu$. Hasil dari kalibrasi amonia ini kemudian dijadikan sebagai dasar untuk menghitung kandungan amonia yang didapat dari hasil pengukuran di spektrofotometri.

\section{Metode Analisis Data}

Hasil pengamatan dianalisis secara grafik dan dijelaskan untuk mengetahui seberapa besar efisiensi removal air limbah RPA dari masing-masing beban hidrolik. Metode grafik dijadikan sebagai acuan dalam melihat penurunan dari parameter yang diamati.

\section{HASIL DAN PEMBAHASAN}

Pengolahan dengan menerapkan teknologi aerobik dianggap kurang cocok untuk air limbah RPA atau RPH karena konsumsi energi yang tinggi untuk aerasi, produksi lumpur yang jumlah besar, dan keterbatasan mentransfer oksigen (Gavala et al, 1996;. Rajeshwari et al, 2000;. Speece, 1996). Proses biologis anaerobik lebih cocok dan telah digunakan untuk mengolah air limbah RPA ini dengan konsentrasi influen yang tinggi. Reaktor anaerobik tingkat tinggi telah dijadikan sebagai alternatif yang baik dan efektif karena banyak keuntungan seperti biaya awal dan operasional yang rendah, kebutuhan ruang yang lebih kecil, tingginya efisiensi penyisihan kandungan bahan organik dan produksi lumpur yang rendah, selain itu proses ini menghasilkan energi bersih melalui produksi biogas yang dapat dimanfaatkan. Kinerja IPAL biofilter menunjukan hasil yang sangat baik, dengan kualitas olahan yang sangat baik.

\section{Senyawa Ammonia}

Keberadaan senyawa amonia dapat menyebabkan kondisi toksik bagi kehidupan perairan. Kadar amonia bebas dalam air meningkat sejalan dengan meningkatnya $\mathrm{pH}$ dan suhu. Kehidupan air terpengaruh oleh amonia pada konsentrasi $1 \mathrm{mg} / \mathrm{L}$ dan dapat menyebabkan mati karena dapat mengurangi konsentrasi oksigen dalam air (Widayat dkk, 2010).

Kandungan amonia yang tinggi dan bahan organik yang rendah merupakan karakteristik utama dari limbah RPA secara anaerobik. Limbah RPA yang mengandung senyawa amonia yang tinggi dengan bahan organik yang rendah dapat dioleh dengan menerapkan sistem teknologi sequencing batch reaktor (SBR) (Shengquan et al, 2008; Keller et al, 1997; Pochana, et al, 1999; Subramaniam, et al, 1994). Konsentrasi bahan organik rendah, oksigen terlarut cukup dan waktu tinggal lumpur yang lama memungkinkan proses nitrifikasi dan denitrifikasi berada pada kondisi yang stabil (De Nardi, et al 2011).

Secara kimia, keberadaan amonia di dalam perairan dapat berupa amonia terlarut $\left(\mathrm{NH}_{3}\right)$ dan ion amonium $\left(\mathrm{NH}_{4}^{+}\right)$. amonia bebas $\left(\mathrm{NH}_{3}\right)$ yang tidak terionisasi bersifat toksik bagi organisme akuatik. Persentase amonia bebas meningkat dengan meningkatnya $\mathrm{pH}$ dan suhu perairan. Menurut Effendi (2003), toksisitas amonia terhadap organisme akuatik dipengaruhi oleh $\mathrm{pH}$, kadar oksigen terlarut, dan suhu. Pada $\mathrm{pH}$ rendah amonia akan bersifat racun jika jumlahnya banyak, sedangkan pada kondisi $\mathrm{pH}$ tinggi amonia akan bersifat racun meskipun kadarnya rendah. Penurunan kadar oksigen terlarut akan meningkatkan toksisitas amonia dalam perairan.

\section{Efisiensi Penurunan Senyawa Ammonia pada Konsentrasi limbah $420 \mathrm{mg} / \mathrm{L}$}

Media sebagai tempat tumbuh dan berkembangbiaknya mikroorganisme pengurai limbah dapat bersumber dari karbon aktif, bioball, pecahan batu kali, kayu, plastik dan lain-lain. Umumnya media yang digunakan berbahan keras dan mudah untuk diperoleh. Media karbon aktif sebagai media tumbuhnya mikroorganisme mampu menyerap senyawa ammonia dalam limbah RPA. Efisiensi penurunan kandungan ammonia yang terjadi pada media bioball seperti yang terlihat pada gambar 2 . 


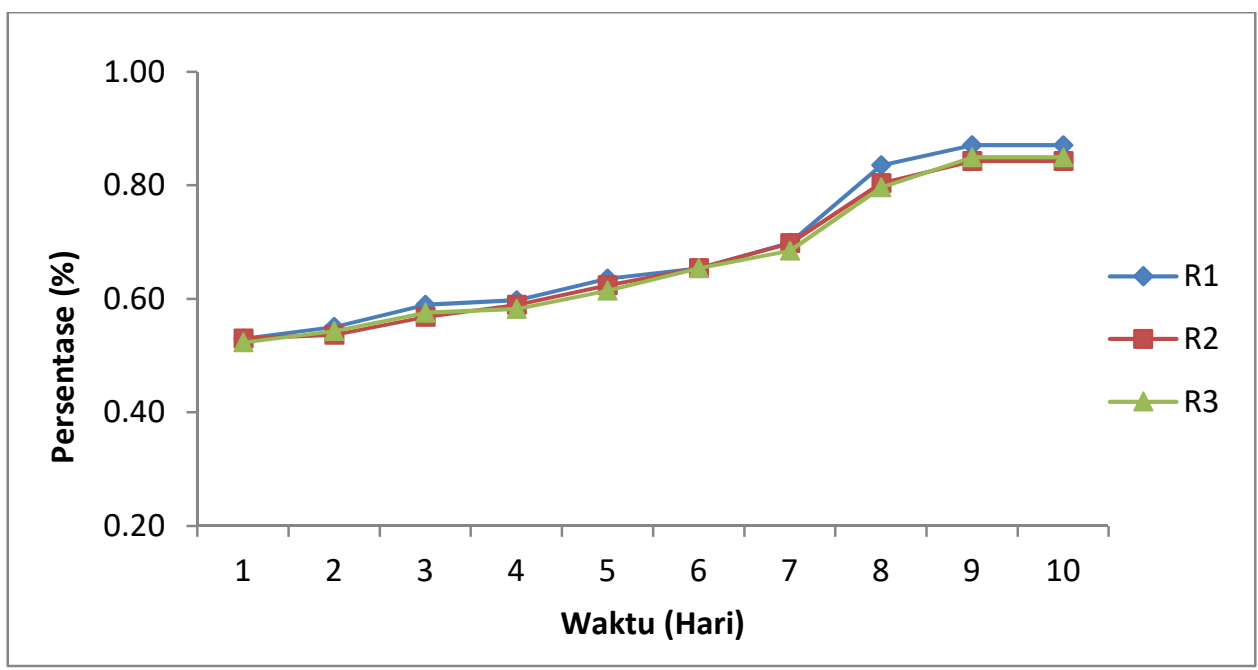

Gambar 2. Penyisihan Senyawa Amonia dengan Konsentrasi Limbah 420 mg/L

Penyisihan kadar amonia pada media karbon aktif menunjukan hasil yang lebih baik Hal ini bisa dilihat dari gambar 2 . Meskipun tidak terjadi perbedaan yang signifikan antara beban hidrolik media, namun tetap memiliki pengaruh yang besar terhadap penyisihan senyawa amonia. Penyisihan terbesar yaitu sebesar $87 \%$ pada beban hidrolik media $0,006 \mathrm{~m}^{3} / \mathrm{m}^{2}$ media.hari, $84 \%$ pada beban hidrolik media 0,009 $\mathrm{m}^{3} / \mathrm{m}^{2}$ media.hari dan $85 \%$ pada beban hidrolik media $0,015 \mathrm{~m}^{3} / \mathrm{m}^{2}$ media.hari. Dengan kata lain pada konsentrasi limbah cair yang asli, beban hidrolik media $0,006 \quad \mathrm{~m}^{3} / \mathrm{m}^{2}$ media.hari memberikan nilai efesiensi penyisihan yang besar dan jika ditinjau dari media penyangga yang digunakan, maka media karbon aktif yang paling efektif dalam menyisihkan kadar amonia. Sedangakan menurut Al Kholif (2015) Efisiensi penurunan kandungan ammonia pada reaktor bermedia bioball menunjukan penurunan yang cukup signifikan yaitu sebesar $80 \%$.
Efisiensi Penurunan Senyawa Amonia dengan Konsentrasi 400 mg/L

Pencernaan anaerobik sangat efisien dan umumnya dioperasikan untuk mengolah bahan organik dalam air limbah (MataAlvarez et al., 2000), sedangkan beberapa nutrisi dalam penguapan limbah seperti nutrisi nitrogen (nitrat, nitrit dan amonia) dan ion logam jarang sekali pernah diperlakukan selama proses pencernaan anaerobik (Chen et al., 2008). Meskipun sebagian dari nutrisi nitrogen digunakan untuk pertumbuhan dan reproduksi mikroorganisme selama proses pencernaan anaerobik, konsentrasi total nutrisi dapat masih dilestarikan pada reaktor anaerobik (Angelidaki dan Ahring, 1993; Kim et al, 2015). Untuk menghilangkan nutrisi nitrogen dalam sampah organik, perlu dilakukan proses dalam menggabungkan pengolahan biologi atau fisika dalam reactor anaerobik (Bonmat1 dan Flotats, 2003;. Kim et al, 2015;. Mata-Alvarez et al, 2000). Jika nutrisi ini kemudian dibuang ke dalam sistem air tanpa pengolahan lebih lanjut, maka akan menyebabkan eutrofikasi pada air permukaan. Di antara nutrisi penting, amonia adalah spesies yang paling dominan yang dibutuhkan sebagai hewan atau kaya protein limbah. 


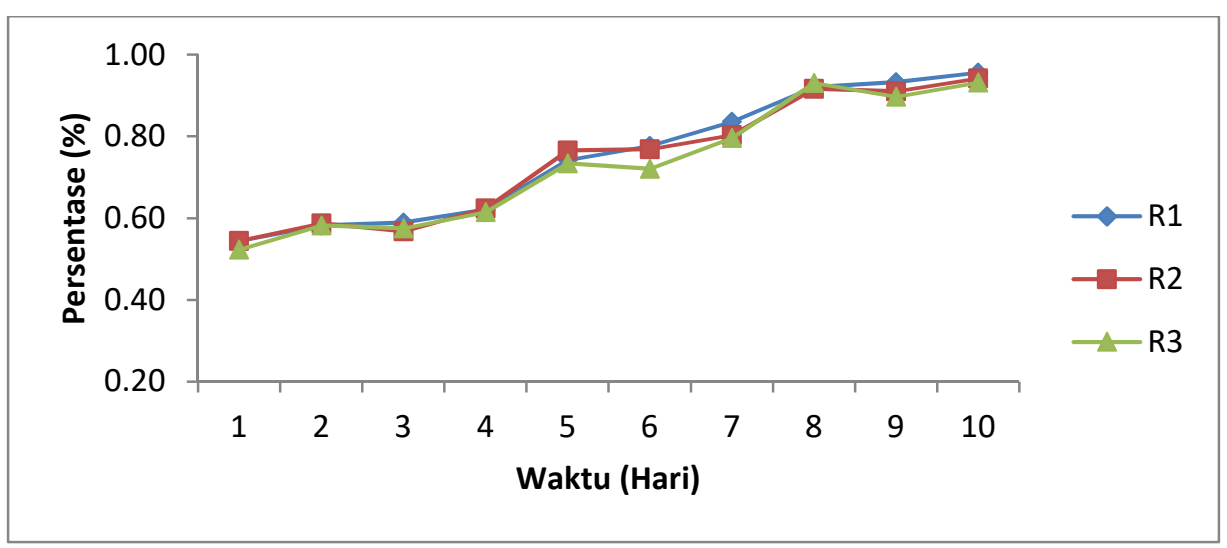

Gambar 3. Penyisihan Senyawa Ammonia dengan Konsentrasi Limbah 400 mg/L

Secara keseluruhan efisiensi tertinggi untuk ketiga variabel terjadi pada variabel beban hidrolik media $0,006 \mathrm{~m}^{3} / \mathrm{m}^{2}$ media.hari. Pada media karbon aktif efisiensi penyisihan mencapai $96 \%$. Peningkatan efisiensi dari hari pertama hingga hari terakhir pengamatan menunjukan peningkatan yang signifikan. Hal ini menandakan bahwa kinerja mikrorganisme dalam menguraikan limbah cair terutama untuk menurunkan kadar ammonia terbilang berhasil. Media karbon aktif lebih besar nilai efisiensinya karena memiliki luas permukaan yang lebih kecil sehingga mampu menyerap kadar ammonia lebih banyak. Penggunaan media pecahan batu kali juga mampu menyisihkan senyawa ammonia pada limbah cair RPA. Penyisihan kandungan ammonia tertinggi yaitu sebesar 75\% pada (Al Kholif, 2015).

\section{Efisiensi Penurunan Senyawa Ammonia dengan Konsentrasi Limbah 380 mg/L}

Proses penyisihan ammonia $\left(\mathrm{NH}_{3}\right)$ pada biofilter menggunakan media kompos matang menyisihkan $\mathrm{NH}_{3}$ sebesar 95\% (Maia $\mathrm{dkk}$, 2012). Pada proses pengolahan air limbah menggunakan sistem biofilter dengan media GAC (Granular Activated Carbon) mampu menyisihkan $\mathrm{NH}_{3}$ sebesar $99 \%$ (Benyouchef dkk, 2013). Sedangkan proses penyisihan nitrogen $(\mathrm{N})$ pada lindi menggunakan biofilter dengan sistem $\mathrm{A}^{2} \mathrm{O}$ mempunyai efisiensi $95,46 \%$ (Han dkk, 2013).

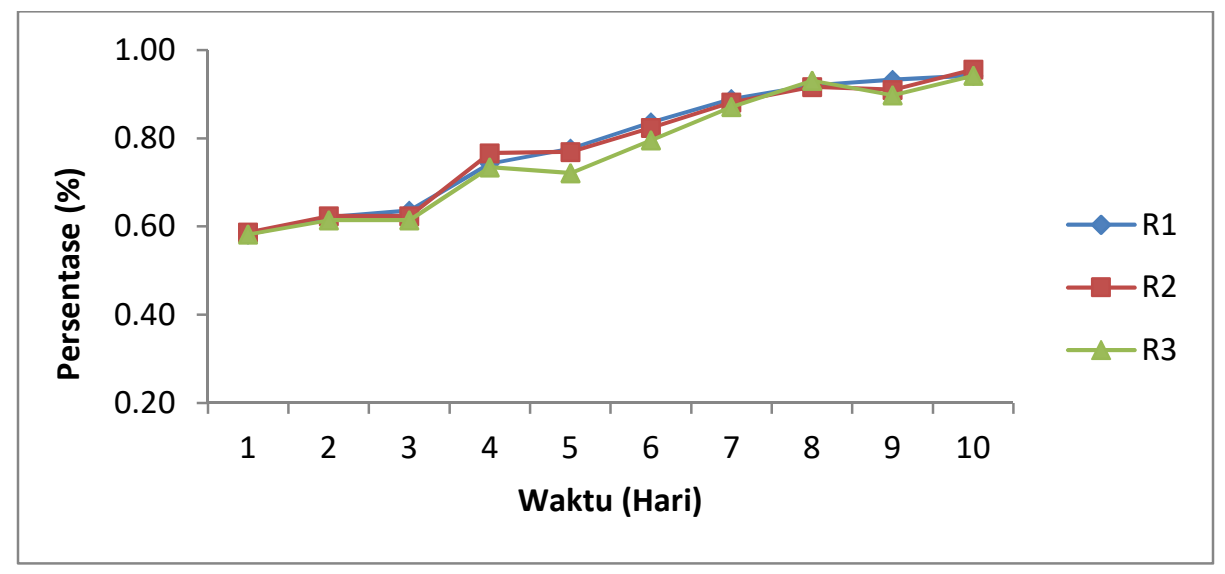

Gambar 4. Penyisihan Senyawa Amonia dengan Konsentrasi Limbah 380 mg/L 
Jika ditinaju dari hasil yang diperoleh dalam penelitian sebelumnya, dimana penggunaan media bioball dan media pecahan batu kali ternyata mampu menyisihkan senyawa ammonia pada limbah RPA (Al Kholif, 2015). Penggunaan media Karbon aktif memiliki peningkatan efisiensi yang lebih besar jika dibandingkan dengan penyisihan kadar ammonia pada media bioball dan media pecahan batu kali. Salah satu faktor yang mempengaruhi adalah peningkatan efisiensi adalah luas permukaan yang kecil dan daya serap beban pencemar yang cukup bagus. Rata-rata penyisihan pada media karbon aktif melebihi 95\%. Pada beban hidrolik media $0,006 \mathrm{~m}^{3} / \mathrm{m}^{2}$ media.hari, media karbon aktif mampu menyisihkan kadar ammonia sebesar 98\%. Pada beban hidrolik media $0,009 \mathrm{~m}^{3} / \mathrm{m}^{2}$.hari mampu menyihkan kadar ammonia pada limbah cair RPA sebesar $96 \%$ dan pada beban hidrolik media $0,015 \mathrm{~m}^{3} / \mathrm{m}^{2}{ }_{\text {media. hari mampu }}$ menyihkan kadar ammonia pada limbah cair RPA sebesar 94\%. Besarnya penyisihan senyawa ammonia yang terjadi pada masingmasing beban hidrolik media dikarenakan banyaknya jumlah media yang terdapat dalam sebuah reaktor pengolahan.

Efisiensi reduksi emisi gas amonia pada biofilter menggunakan media komposmatang mencapai $87,96 \%$, sedangkan menggunakan media GAC mencapai 99,51\%. Model adsorpsi yang sesuai pada proses adsorpsi media GAC yaitu isoterm Langmuir, sedangkan pada media kompos matang yaitu isoterm BET (Tri Rahmawati, dkk, 2013).

\section{KESIMPULAN}

Hasil analisis dapat disimpulkan bahwa penyisihan beban pencemar limbah cair RPA dari masing-masing beban hidrolik media secara keseluruhan mampu menyerap senyawa ammonia. Penyisihan terbaik terjadi pada beban hidrolik media $0,006 \mathrm{~m}^{3} / \mathrm{m}^{2}$.hari dengan tinggat efisiensi terbesar sebanyak 98\% pada konsentrasi limbah $380 \mathrm{mg} / \mathrm{L}$.

\section{Ucapan Terima Kasih}

Penelitian ini telah mendapatkan dukungan dari dekan, ketua jurusan Teknik Lingkungan, dan kepala laboratorium Teknik Lingkungan Universitas PGRI Adi Buana Surabaya. Selain itu disampaikan ucapan terimakasih kepada Herlando yang telah banyak membantu dalam penelitian ini serta LPPM UNIPA Surabaya dan Kemenristek DIKTI atas dukungan dana yang diberikan kepada peneliti.

\section{DAFTAR PUSTAKA}

Al Kholif M.; Hermana J. 2013. The Wastewater Treatment of Chicken Slaughterhouse by Using Submerged Up Flow Anaerobic Biofilter. Proceeding International Seminar on Environmental Engineering (ISEE, 2013), 484-490.

Al Kholif, M (2015). Pengaruh Penggunaan Media Dalam Menurunkan Kandungan Amonia Pada Limbah Cair Rumah Potong Ayam (Rpa) Dengan Sistem Biofilter Anaerob. Jurnal WAKTU Volume 13 Nomor 1 Januari 2015 : 13-18

Angelidaki, I., Ahring, B., 1993. Thermophilic anaerobic digestion of livestock waste: the effect of ammonia. Appl. Microbiol. Biotechnol. 38 (4), 560-564.

Bayr, S., Rantanen, M., Kaparaju, P., Rintala, J., 2012. Mesophilic and thermophilic anaerobic codigestion of rendering plant and slaughterhouse wastes. Bioresour. Technol. 104, 28-36.

Benyoucef, N., Cheikh, A., Drouiche, N., Lounici, H., Mameri, N., dan Abdi, N. (2013), "Denitrification of Groundwater Using Brewer's Spent Grain as Biofilter Media", Ecological Engineering, Vol. 52, hal. 70-74. 
Bonmati, A., Flotats, X., 2003. Air stripping of ammonia from pig slurry: characterisation and feasibility as a pre- or post-treatment to mesophilic anaerobic digestion. Waste Manage. 23 (3), 261-272.

Chen, Y., Cheng, J.J., Creamer, K.S., 2008. Inhibition of anaerobic digestion process: a review. Bioresour. Technol. 99 (10), 4044-4064

Cuetos, M.J., Gomez, X., Otero, M., Morán, A., 2008. Anaerobic digestion of solid slaughterhouse waste (SHW) at laboratory scale: Influence of co-digestion with the organic fraction of municipal solid waste (OFMSW). Biochem. Eng. J. 40, 99-106.

De Nardi,I.R., V. Del Nery, A.K.B. Amorim, N.G. dos Santos, F. Chimenes, Performances of SBR, Chemical-DAF and UV Disinfection for Poultry Slaughterhouse Wastewater Reclamation, Desalination, 269 (2011) 184-189.

Del Nery V, Damianovic MHZ, Barros FG. The Use of an Upflow Anaerobic Sludge Blanket Reactor in the Treatment of Poultry Slaughterhouse Wastewater. Water Sci Technol 2001a; $44(4): 83-89$.

Effendi, Hefni. 2003. Talaah Kualitas Air : Bagi Pengelolaan Sumber Daya Alam dan Lingkungan Perairan. Yogyakarta : Penerbit Kanisius.

Gavala, H. N., Skiadas, I. V., Nikolaos, A. B., Lyberatos, G. (1996) Anaerobic digestion of agricultural industries wastewaters. Water Science and Technology, 34 (11), 67-75.

Han, Z., Liu, D., dan Li, Q. (2013), "A Removal Mechanism for Organics and Nitrogen in Treating Leachate Using a Semi-Aerobic Aged Refuse Biofilter", Journal of Environmental Management, Vol. 114, hal. 336-342.

Jetten, M.S., Wagner, M., Fuerst, J., van Loosdrecht, M., Kuenen, G., Strous, M., 2001. Microbiology and application of the anaerobic ammonium oxidation ('anammox') process. Curr. Opin. Biotechnol. 12 (3), 283-288.

Karlsson, A., Ejlertsson, J., 2012. Addition of $\mathrm{HCl}$ as a means to improve biogas production from protein-rich food industry waste. Biochem. Eng. J. 61, 43-48.

Keller, J., Subramaniam, K., J. Gösswein, P.F. Greenfield, 1997. Nutrient Removal from Industrial Wastewater Using Single Tank Sequencing Batch Reactors, Water Sci. Technol. 35 (6) (1997) 137-144.

Keller, J., Subramaniam, K., J. Gösswein, P.F. Greenfield, 1997. Nutrient Removal from Industrial Wastewater Using Single Tank Sequencing Batch Reactors, Water Sci. Technol. 35 (6) (1997) 137-144.

Kim, J.R., Zuo, Y., Regan, J.M., Logan, B.E., 2008. Analysis of ammonia loss mechanisms in microbial fuel cells treating animal wastewater. Biotechnol. Bioeng. 99 (5), 1120-1127

Kim, T., An, J., Jang, J.K., Chang, I.S., 2015. Coupling of anaerobic digester and microbial fuel cell for COD removal and ammonia recovery. Bioresour. Technol. 195, 217-222.

Koster, I.W., Koomen, E., 1988. Ammonia inhibition of the maximum growth rate $\left(\mu_{\mathrm{m}}\right)$ of hydrogenotrophic methanogens at various $\mathrm{pH}-\mathrm{levels}$ and temperatures. Appl. Microbiol. Biotechnol. 28, 500-505.

Kuntke, P., S, miech, K., Bruning, H., Zeeman, G., Saakes, M., Sleutels, T., Hamelers, H., Buisman, C., 2012. Ammonium recovery and energy production from urine by a microbial fuel cell. Water Res. 46 (8), 2627-2636.

Maia, G.D.N., Day, G.B., Gates, R.S., dan Taraba, J.L. (2012), “Ammonia Biofiltration and Nitrous Oxide Generation During The Start-up of Gas Phase Compost Biofilters", Atmospheric Environment, Vol. 45, hal. 659664.

Mata-Alvarez, J., Macé, S., Llabrés, P., 2000. Anaerobic digestion of organic solid wastes. An overview of research achievements and perspectives. Bioresour. Technol. 74 (1), 3-16.

Münch, E.V., Lant, P., Keller, J., 1996. Simultaneous nitrification and denitrification in bench-scale sequencing batch reactors. Water Res. 30 (2), 277-284. 
Obaja, D., Mace, S., Costa, J., Sans, C., Mata-Alvarez, J., 2003. Nitrification, denitrification and biological phosphorus removal in piggery wastewater using a sequencing batch reactor. Bioresour. Technol. 87 (1), 103-111.

Peraturan Gubernur Jawa Timur Nomor 72 tahun 2013 tentang Baku Mutu Air Limbah Bagi Industri dan/atau Kegiatan Usaha Lainnya.

Pochana, K., Keller, J. 1999. Study of Factors Affecting Simultaneous Nitrification and Denitrification (SND), Water Sci. Technol. 39 (6) (1999) 61-68.

Rajeshwari, K. V., Balakrishnan, M., Kansal, A., Lata, K. and Kishore, V.V.N. (2000) State-of-theart of anaerobic digestion technology for industrial wastewater treatment. Renewable and Sustainable Energy Reviews, 4 (2), 135-156.

Salminen, E.A., Rintala, J.A., 2002. Semi-continuous anaerobic digestion of solid poultry slaughterhouse waste: effect of hydraulic retention time and loading. Water Res. 36, 31753182.

Shengquan Y, G. Siyuan, W. Hui. High Effective to Remove Nitrogen Process in Abattoir Wastewater Treatment, Desalination 222 (2008) 146-150.

Speece, R. E. (1996). Anaerobic Biotechnology for Industrial Wastewaters, Archae Press, Nashville, TN.

Subramaniam, K., P.F. Greenfield, K.M. Ho, M.R. Johns, J. Keller, 1994. Efficient Biological Nutrient Removal in High Strength Wastewater Using Combined Anaerobic Sequencing Batch Reactor Treatment, Water Sci. Technol. 30 (6) (1994) 315-321.

Sugito, B D Karunia and Al Kholif, M., 2016. The effect of BOD Concentrate influetn to Remove Pollutant Load in Wastewater of a Chicken Slaughterhouse. ARPN Journal of Engineering and Applied Sciences. Vol. 11 No. 5: 3519-3524.

Tarntip.R., S. Thungkao. 2011. Isolation of Proteolytic, Lipolytic, and Bioemulsifying Bacteria for Improvement of the Aerobic Treatment of Poultry Processing Wastewater. Afr. J. Microbiol. Rsc 5 (2) : 30-35

Tri Rahmawati, Rhenny Ratnawati dan Yulinah Trihadiningrum, 2013. Reduksi Emisi Amonia Menggunakan Biofilter Pada Proses Pengomposan Limbah Padat Rumah Potong Hewan Dengan Sistem Five Stage Sequencing Batch Reactor. Seminar Nasional Pascasarjana XIII ITS Surabaya 2013.

Widayat Wahyu, Suprihatin dan Arie Herlambang. 2010. Penyisihan Amoniak dalam Upaya Meningkatkan Kualitas Air Baku PDAM-IPA Bojang Renged dengan Proses Biofiltrasi Menggunakan Media Plastik Tipe Sarang Tawon. Jurnal Teknologi Lingkungan Volume VI (1) : $64-76$ 